\title{
Phenobarbital Effects on Brain and Liver Tissues Enzyme Activity in Balb/C Mice
}

\author{
E. YAZAR ${ }^{1 *}$, O. DEMIR ${ }^{2}$, M. ELMAS ${ }^{1}$, A. L. BAS ${ }^{1}$, B. TRAS ${ }^{1}$ \\ ${ }^{1}$ Department of Pharmacology and Toxicology, Faculty of Veterinary Medicine, \\ University of Selcuk, Konya, Turkey \\ ${ }^{2}$ Department of Neurology, Faculty of Medicine, University of Selcuk, Konya, Turkey
}

Received October 8, 2001

Accepted June 19, 2002

Abstract

Yazar, E., O. Demir, M. Elmas, A. L. Bas, B. Tras: Phenobarbital Effects on Brain and Liver Tissues Enzyme Activity in Balb/C Mice. Acta Vet. Brno 71, 2002: 309-312.

The purpose of the present study was to investigate the effect of phenobarbital on some brain and liver tissue enzyme activities in Balb/C mice. Forty male Balb/C mice were used. Ten mice served as a control group, and thirty mice were administered with phenobarbital ( 80 $\mathrm{mg} \cdot \mathrm{kg}^{-1}$ body mass, single oral dose). Brain and liver samples were taken at 6,12 and $24 \mathrm{~h}$ after drug administration. Brain and liver tissues alkaline phosphatase, aspartate aminotransferase, gamma glutamyl transferase and amylase activities were measured by autoanalyzer.

Phenobarbital did not affect gamma glutamyl transferase and amylase activities in the brain and liver, and alkaline phosphatase and aspartate aminotransferase activities in the liver. However, statistically significant $(p<0.05)$ increases of alkaline phosphatase and aspartate aminotransferase activities were observed in the brain. In general, after phenobarbital administration, serum alkaline phosphatase and aspartate aminotransferase activities increase and these increases are believed to be derived from the liver. These result suggest that brain may contribute to increased activities of these enzymes in serum in Balb/C mice.

Phenobarbital, liver, brain, enzyme, mouse

Phenobarbital (PB) is a major drug in the treatment of canine, feline and human epilepsy and can significantly reduce the severity of seizures. PB raises the threshold for seizure discharge and inhibits the initiation, diffusion, and spread of discharge from the neural focus. Drug is rapidly and completely absorbed after oral doses and clinically effective 12 to $24 \mathrm{~h}$ after oral administration. PB is metabolized by liver and extracted by the kidney (B arragry 1994; Foster et al. 2000; Gieger et al. 2000).

Common side effects of $\mathrm{PB}$ are ataxia, sedation, polyuria, polydipsia, polyphagia, and it may depress both the respiratory drive and the mechanisms responsible for the rhythmic character of respiration (Hobbs 1996; B ooth 1998; Branum et al. 1998). In addition to these side effects, PB stimulates the division of liver cells (Alberts et al. 1998) and causes increases in serum alkaline phosphatase (ALP), aspartate aminotransferase (AST) and gamma glutamyl transferase (GGT) activities (Aiges et al. 1980; Luoma et al. 1980; Verma and Haidukewych 1994; Chauvet et al. 1995).

ALP, AST and GGT enzymes are accepted as indicators of hepatotoxicity (B oyd 1982; Is ogai et al. 1994; Rosenthal 1997). Also, GGT and ALP are present in blood-brain barrier (Brust et al. 1994; Agrawal et al. 1996; El-Hafny et al. 1996; Lawrenson et al. 1999). Amylase (AM) is an especially accepted pancreatic enzyme. However, in the body, AM is present in a number tissues such as salivary glands, semen, testes, lungs, adipose tissue and liver. In addition to this, cerebral trauma has also been associated with hyperamylasemia (Moss and Henders on 1994).

Address for correspondence:

Dr. Enver Yazar

Department of Pharmacology and Toxicology,

Faculty of Veterinary Medicine
Phone: +90 3322410041

e-mail: eyazar@selcuk edu tr

http://www.vfu.cz/acta-vet/actavet.htm 
The aim of the current study was to investigate the effect of phenobarbital on ALP, AST, GGT and AM activities of brain and liver tissues in Balb/C mice.

\section{Materials and Methods}

Forty male Balb/C (aged approximately 5 months, body mass 38-44 g) mice were used in the experiment (Selcuk University, Experimental Medicine, Research and Application Center, Konya, Turkey). Mice were fed a standard pellet diet and tap water ad libitum during the entire experimental period. Ten mice were used as a control group. Thirty mice were administered PB (Luminaletten ${ }^{\circledR}$, Bayer, Istanbul) via intragastric gavage needle at doses 80 $\mathrm{mg} \cdot \mathrm{kg}^{-1}$ body wt, orally (Yuschak and Gautieri 1993; Yazar et al. 2001). After the administration of PB, ten mice were randomly selected and killed at 6,12 and $24 \mathrm{~h}$.

Brain (cerebrum) and liver (300 mg, lobus hepatis sinister) samples were immediately removed and washed with cold $\left(+4{ }^{0} \mathrm{C}\right)$ saline solution after killing. Samples were homogenized with $500 \mu \mathrm{l}$ of cold $\left(+4{ }^{0} \mathrm{C}\right)$ homogenate solution (0.25 M sucrose (Sigma) + $10 \mathrm{mM}$ Tris (Sigma) + $1 \mathrm{mM}$ EDTA (Pharmacia Biotech), pH 7.4) into ice (Vani et al. 1990; Yazar and Tras 2001). The homogenates were centrifuged $\left(11.150 \mathrm{~g}, 15 \mathrm{~min},+4^{\circ} \mathrm{C}\right)$, and the supernatants were carefully removed and stored for analysis $\left(-80^{\circ} \mathrm{C}\right)$. Brain and liver tissues ALP (EC:3.1.3.1.), AST (EC:2.6.1.1.), GGT (EC:2.3.2.2.), AM (EC:3.2.1.1.) and protein levels were measured using an auto analyzer (Olympus 5200, Japan).

All values are expressed as mean \pm SEM. The results were analyzed by a parametric Tukey HSD multiple range test (SPSS for Windows, release 6.0). In all cases, probability of error of less than 0.05 was selected as the criterion for statistical significance from the control values.

\section{Results}

Brain and liver tissues ALP, AST, GGT and AM activities are given in Table 1. Brain tissue ALP and AST activities increased $(p<0.05)$ at 12 and $24 \mathrm{~h}$ when compared with control group.

Table 1

Effect of phenobarbital (PB) on brain and liver tissues alkaline phosphatase (ALP), aspartate aminotransferase (AST), gamma glutamyl transferase (GGT) and amylase (AM) activities in Balb/C mice (mean \pm SEM, $n=40$ )

\begin{tabular}{|l|c|c|c|c|}
\hline & \multicolumn{1}{|c|}{$\begin{array}{c}\text { Control } \\
(\mathrm{n}=10)\end{array}$} & $\begin{array}{c}6^{\text {th }} \text { hour } \\
(\mathrm{na}=10)\end{array}$ & $\begin{array}{c}12^{\text {th }} \text { hour } \\
(\mathrm{n}=10)\end{array}$ & $\begin{array}{c}2^{\text {th }} \text { hour } \\
(\mathrm{na}=10)\end{array}$ \\
\hline $\begin{array}{l}\text { Brain } \\
\text { ALP U.mg } \\
\text { Tissue protein }\end{array}$ & $60.90 \pm 4.63$ & $70.77 \pm 9.21$ & $87.06 \pm 4.19^{*}$ & $89.29 \pm 6.65^{*}$ \\
\hline $\begin{array}{l}\text { AST U.mg } \\
\text { Tissue protein }\end{array}$ & $121.67 \pm 8.11$ & $124.62 \pm 5.52$ & $147.07 \pm 5.13^{*}$ & $151.74 \pm 9.63^{*}$ \\
\hline $\begin{array}{l}\text { GGT U.mg } \\
\text { Tissue protein }\end{array}$ & $4.85 \pm 0.51$ & $4.61 \pm 1.25$ & $5.01 \pm 1.43$ & $4.78 \pm 1.51$ \\
\hline $\begin{array}{l}\text { AM U.mg } \\
\text { Tissue protein }\end{array}$ & $4.36 \pm 0.59$ & $5.22 \pm 0.55$ & $5.47 \pm 0.62$ & $5.57 \pm 0.48$ \\
\hline $\begin{array}{l}\text { Liver } \\
\text { ALP U.mg-1 } \\
\text { Tissue protein }\end{array}$ & $11.01 \pm 0.99$ & $9.30 \pm 1.10$ & $8.45 \pm 0.55$ & $8.25 \pm 0.66$ \\
\hline $\begin{array}{l}\text { AST U.mg } \\
\text { Tissue protein }\end{array}$ & $709.00 \pm 25.40$ & $661.50 \pm 41.97$ & $667.44 \pm 32.72$ & $616.43 \pm 43.05$ \\
\hline $\begin{array}{l}\text { GGT U.mg } \\
\text { Tissue protein }\end{array}$ & $4.33 \pm 0.65$ & $3.94 \pm 0.30$ & $4.37 \pm 0.61$ & $4.92 \pm 0.43$ \\
\hline $\begin{array}{l}\text { AM U.mg } \\
\text { Tissue protein }\end{array}$ & $8.07 \pm 1.15$ & $8.82 \pm 0.49$ & $6.29 \pm 0.52$ & $6.69 \pm 0.52$ \\
\hline
\end{tabular}

$* p<0.05$ significantly different from control group 


\section{Discussion}

In the present study, it was observed that while brain tissue ALP and AST activities increased significantly $(p<0.05)$ at 12 and $24 \mathrm{~h}$, no significant alterations were observed in hepatic ALP and AST activities after PB administration. ALP and GGT were strongly present in cortical capillaries of blood-brain barrier (Brust et al. 1994; Agraval et al. 1996; Law ren s on et al. 1999). PB has been evaluated in rodent models of epilepsy in many studies (Loscher et al. 1988; King and LaMotte 1989; B ac et al. 1998) and caused increases in serum ALP, AST and GGT activities (Luoma et al. 1980; Aiges et al. 1980; Verma and Haidukewych 1994; Chauvet et al. 1995). In addition, AST activity alterations were mainly due to PB (Verma and Haidukewych 1994). Many studies reported that PB caused increases in serum AST (Fortman and Witte 1985; Haidukewych and John 1986; Kitchin and Brown 1987) and ALP activities (Chauvet et al. 1995; Filardi et al. 2000; Foster et al. 2000). In the present study, brain tissue ALP and AST activities increased significantly, but no changes were observed in the liver. ALP and AST are present in many organs such as heart, skeletal muscle, intestine, bone and kidney excluding liver (Rosenthal 1997). Damage occurring in these tissues caused by drugs can cause increases in serum ALP and AST activities (Tardivel et al. 1992; Rosenthal 1997). GGT activities in brain and liver tissue were not affected by PB in the current study. It was earlier stated that only phenytoin seemed to be responsible for the elevation of GGT activity (S ano et al. 1981), and no effect in the serum GGT activity was observed following PB administration in healthy dogs (Gieger et al. 2000).

It is concluded that PB caused increases in brain tissue ALP and AST activities. Increased serum ALP and AST levels may not be derived from the liver only after PB treatment, other tissues possessing these enzymes may contribute to their increases serum activities.

Vliv fenobarbitalu na aktivitu některých enzymů jaterní a mozkové tkáně myší Balb/C

Předmětem studie bylo posouzení účinku fenobarbitalu na aktivitu některých enzymů jaterní a mozkové tkáně myší Balb/C. Bylo použito čtyřicet myší Balb/C samčího pohlaví. Deset zvířat sloužilo jako kontrolní skupina a čtyřiceti myším byl podán fenobarbital (80 $\mathrm{mg} / \mathrm{kg}$ tělesné hmotnosti, perorálně, individuálním podáním). Vzorky mozkové a jaterní tkáně byly odebrány 6,12 a 24 hodin po podání preparátu.

Ve tkáních mozku a jater byla stanovena na autoanalyzátoru aktivita alkalické fosfatasy , aspartátaminotransferasy, gama-glutamyltransferasy a amylasy. U žádné z těchto tkání fenobarbital neovlivnil tkání aktivitu gamma-glutamyltransferasy a amylasy, ani aktivitu jaterní alkalické fosfatasy a aspartátaminotransferasy. Způsobil však zvýšení aktivity alkalické fosfatasy a aspartátaminoransferasy v mozkové tkáni. Zvýšení aktivity těchto enzymů v mozku se může podílet i na zvýšení jejich aktivity v krevním séru po podání fenobarbitalu.

\section{References}

AGRAWAL, A, SHUKLA, R, TRIPATHI, LM, PANDEY, VC, SRIMAL, RC 1996: Permeability function related to cerebral microvessel enzymes during ageing in rats. Int J Dev Neurosci 14: 87-91

AIGES, HW, DAUM, F, OLSON, M, KAHN, E, TEICHBERG, S 1980: The effect of phenobarbital and diphenylhydantoin on liver function and morphology. J Pediatr 97: 22-26.

ALBERTS, B, BRAY, D, JOHNSON, A, LEWIS, J, WALTER, P, ROBERTS, K, RAFF, M. 1998: Essential Cell Biology: An Introduction to the Molecular Biology of the Cell, Garland Publishing, NY, USA.

BAC, P, MAUROIS, P, DUPONT, C, PAGES, N, STABLES, JP, GRESSENS, P, EVRARD, P, VAMECQ, J 1998: Magnesium deficiency depended audiogenic seizures (MDDASs) in adult mice: A nutritional model for discriminatory screening of anticonvulsant drugs and original assessment of neuroprotection properties. $\mathrm{J}$ Neurosci 18: 4363-4373

BARRAGRY, TB 1994: Veterinary Drug Therapy. Lea \& Febiger, Phidelphia, USA, pp. 990-1000 
BOOTH, NH 1998: Hypnotics, sedatives, and anticonvulsants. Veterinary Pharmacology and Therapeutics, $6^{\text {th }}$ edition, Iowa State University Press, Ames, USA, pp. 275-290

BOYD, JW 1982: The mechanism relating to increases in plasma enzymes and isoenzymes in disease of animals. Vet Clin Pathol 12: 9-34

BRANUM, GD, SELIM, N, LIU, X, WHALEN, R, BOYER, TD 1998: Ischaemia and reperfusion injury of rat liver increases expression of glutathione S-transferase A1/A2 in zone 3 of the hepatic lobule. Biochem J 330: 73-79

BRUST, P, BECH, A, KRETZSCHMAR, R, BERGMANN, R 1994: Developmental changes of enzyme involved in peptide degradation in isolated rat brain microvessels. Peptides 15: 1085-1088

CHAUVET, AE, FELDMAN, EC, KASS, PH 1995: Effect of phenobarbital administration on results of serum biochemical analyses and adrenocortical function tests in epileptic dog. J Am Vet Med Assoc 207: 1305-1307

DEMIR, O, YAZAR, E, ALTUNOK, V, ELMAS, M, OZDEMIR, V 2001: Effect of phenobarbital on antioxidant enzyme activities and blood gas parameters in Balb/C mice. Rev Med Vet 152: 723-726

EL-HAFNY, B, BOURRE, JM, ROUX, F 1996: Synergistic stimulation of gamma-glutamyl transpeptidase and alkaline phosphatase activities by retinoic acid and astroglial factors in immortalized rat brain microvessel endothelial cells. J Cell Physiol 167: 451-460

FILARDI, S, GUERREIRO, CAM, MAGNA, LA, NETO, JFM 2000: Bone mineral density, vitamin D and anticonvulsant therapy. Arq Neuropsiquiatr 58: 616-620

FORTMAN, CS, WITTE, DL 1985: Serum 5'-nucleotidase in patients receiving anti-epileptic drug. Am J Clin Pathol 84: 197-201

FOSTER, SF, CHURCH, DB, WATSON, AD 2000: Effects of phenobarbitone on serum biochemical tests in dogs. Aust Vet J 78: 23-26

GIEGER, TL, HOSGOOD, G, TABOADA, J, WOLFSHEIMER, KJ, MUELLER, PB 2000: Thyroid function and serum hepatic enzyme activity in dogs after phenobarbital administration. J Vet Intern Med 14: 277-281

HAIDUKEWYCH, D, JOHN, G 1986: Chronic valproic acid and coantiepileptic drug therapy and incidence of increases in serum liver enzymes. Ther Drug Monit 8: 407-410

HOBBS, WR, RALL, TW, VERDOORN, TA 1996: Hypnotics and sedatives; Ethanol in Pharmacological Basis of Therapeutics, $9^{\text {th }}$ edition, McGraw-Hill Companies, New York, USA, pp. 361-369

ISOGAI, M, OISHI, K, SHIMOKAWA, N, YAMAGUCHI, M 1994: Expression of hepatic calcium-binding protein regucalcin mRNA is decreased by phenobarbital administration in rats. Mol Cell Biochem 141: 15-19

KING, JT, LaMOTTE, CC 1989: El mouse as focal epilepsy: a review. Epilepsia 30: 257-265

KITCHIN, KT, BROWN, JL 1987: Biochemical effects of two promoters of hepatocarcinogenesis in rats. Food Chem Toxicol 25: 603-607

LAWRENSON, JG, REID, AR, FINN, TM, ORTE, C, ALLT, G 1999: Cerebral and pial microvessels: differential expression of gamma glutamyl transpeptidase and alkaline phosphatase. Anat Embryol 199: 29-34

LOSCHER, W, NOLTING, B, HONACK, D 1988: Evaluation of CPP, a selective NMDA antagonist, in various rodent models of epilepsy. Comparison with other NMDA antagonists, and with diazepam and phenobarbital. Eur J Pharmacol 152: 9-17

LUOMA, PV, HEIKKINEN, JE, YLOSTALO, PR 1980: Changes in thyroid function tests during phenobarbital treatment in late pregnancy. Int J Gynaecol Obstet 17: 462-464

MOSS, DW, HENDERSON, R 1994: Enzymes in Clinical Chemistry, W.B. Saunders Company, Philadelphia, USA, pp. 851-877

ROSENTHAL, P 1997: Assessing liver function and hyperbilirubinemia in the newborn. Clin Chem 43: 228-234

SANO, J, KAWADA, H, YAMAGUCHI, N, KAWAKITA, M, KOBAYASHI, K 1981: Effects of phenytoin on serum gama glutamyl transpeptidase activity. Epilepsia 22: 331-338

TARDIVEL, S, BANIDE, H, POREMBSKA, Z, DUPUIS, Y, AYMARD, P, LACOUR, B 1992: In vitro inhibition of alkaline phosphatase activities from intestine, bone, liver and kidney by phenobarbital. Enzyme 46: 276-283

VANI, M, REDDY, G, REDDY, R, THYAGARAJUK, K, REDANNA, P 1990: Glutathione-S-transferase, superoxide dismutase, xantine oxidase, catalase, glutathione peroxidase and lipid peroxidation in the liver of exercised rat. Biochem Int 21: 17-26

VERMA, NP, HAIDUKEWYCH, D 1994: Differential but infrequent alterations of hepatic enzyme levels and thyroid hormone levels by anticonvulsant drugs. Arch Neurol 51: 381-384

YAZAR, E, TRAS, B 2001: Effects of flouroquinolone antibiotics on hepatic superoxide dismutase and glutathione peroxidase activities in healthy and experimentally induced peritonitis mice. Rev Med Vet 152: 235-238

YUSCHAK, MM, GAUTIERI, RF 1993: Teratogenicity of 13-cis retinoic acid and phenobarbital sodium in CF1 mice. Res Commun Chem Pathol Pharmacol 82: 259-278 